UNDERGRADUATE RESEARCH IN NATURAL AND CLINICAL SCIENCE AND TECHNOLOGY (URNCST) JOURNAL Read more URNCST Journal articles and submit your own today at: https://www.urncst.com

\title{
Co-Administration of Menstrual Blood-Derived Stem Cells and Remdesivir for the Treatment of Severe Coronavirus Disease 2019 (COVID-19) Induced Pneumonia: A Research Protocol
}

Andrew J. W. Cao, HBSc Student [1]*, Daniel Jeyaraj, BHSc Student [2], Henry Liu, BHSc Student [2]

[1] Department of Biology, University of Ottawa, Ottawa, Ontario, Canada K1N 6N5

[2] Faculty of Health Sciences, Queen's University, Kingston, Ontario, Canada K7L 3N6

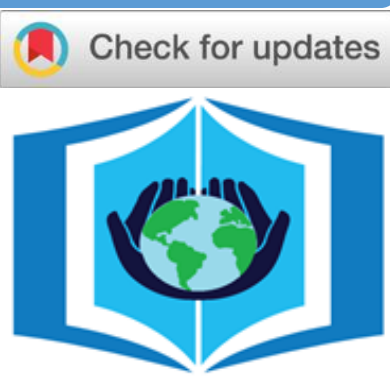

URNCST Journal

"Research in Earnest"

*Corresponding Author: acao077@uottawa.ca

\begin{abstract}
Introduction: Remdesivir (Veklury), a viral ribonucleic acid (RNA)-dependent RNA polymerase inhibitor designed by Gilead Sciences, has shown reductions in recovery time for coronavirus disease 2019 (COVID-19) patients, although its efficacy remains controversial. It has been proposed that combining remdesivir with immunomodulators may improve clinical efficacy. Mesenchymal stem cells (MSCs) exert immunomodulatory properties, which resolve COVID-19-induced pneumonia in early-phase trials. Menstrual blood-derived stem cells (MenSCs) present a novel MSC source, superior in availability, proliferative ability, and ethicality than traditional stem cell sources. This study aims to investigate the efficacy of remdesivir-MenSC combination therapy in resolving severe COVID-19-induced pneumonia.

Methods: A randomized, double-blind, controlled study will be performed to assess two primary endpoints: time of recovery, defined as no longer requiring ongoing medical care, and normalization of the immune system, defined as the change in the concentration of key cytokines from baseline. Safety will also be measured as the frequency of treatmentrelated adverse events (AE). The study will aim to recruit 400 eligible subjects, aged 18 to 75 , hospitalized with severe COVID-19, and they will be assigned to either receive intravenous (IV) infusions of MenSCs and remdesivir, or receive only remdesivir. A stratified log-rank test will be conducted to compare the time of recovery between study arms, with stratification by disease severity (baseline ordinal score). Two-way repeated measures ANOVA will be used to compare cytokine levels over time in the treatment group compared to the control group.

Discussion: We expect remdesivir-MenSC combination therapy to surpass remdesivir in clinical efficacy and safety profile by improving clinical status, lowering duration of hospitalization, reducing mortality, and lowering the incidence of treatment-related AEs.

Conclusion: Investigating this promising approach is an essential step in determining the feasibility of stem cell-based treatments in improving current COVID-19 therapeutics and patient outcomes. In particular, evaluating the clinical potential of MenSCs may provide insight into future therapeutic research as the literature has shown that MenSCs are superior to traditional MSC sources.
\end{abstract}

Keywords: COVID-19; SARS-CoV-2; mesenchymal stem cells; menstrual blood-derived stem cells; remdesivir; combination therapy; pneumonia; ARDS; cytokine storm syndrome

\section{Introduction}

In December 2019, the novel coronavirus Severe Acute Respiratory Syndrome Coronavirus 2 (SARS-CoV-2) was identified as the cause of an outbreak of pneumonia cases in Wuhan, China [1]. This outbreak of COVID-19 is the cause of a global pandemic [1]. The World Health Organization (WHO) declared the outbreak a "Public Health Emergency of International Concern" (PHEIC) on 30 January 2020, followed by a "pandemic" on 11 March 2020 [2]. As of 17 October 2021, there are over 239 million confirmed cases of COVID-19, including nearly 4.9 million deaths [3].
SARS-CoV-2 is an enveloped positive-strand RNA coronavirus, closely related to Severe acute respiratory syndrome coronavirus 1 (SARS-CoV-1) [4]. Around late 2020, variants of the original SARS-CoV-2, the Alpha, Beta, Gamma, and Delta variants, emerged due to persistent transmission and are known as variants of concern (VOCs) [5]. VOCs are verified variants with increased transmissibility, virulence, or pathogenicity [6-8]. Variants of Interest (VOIs) are emerging variants of SARS-CoV-2 which have mutations associated with changes in virulence which have not been fully verified and validated [9]. The 
UNDERGRADUATE RESEARCH IN NATURAL AND CLINICAL SCIENCE AND TECHNOLOGY (URNCST) JOURNAL Read more URNCST Journal articles and submit your own today at: $\underline{\text { https://www.urncst.com }}$

Delta variant is the most infectious strain and has spread globally, becoming the predominant strain in Europe and North America [10-12]. The VOCs and emerging VOIs are poorly understood, warranting further study [6,7].

Patients with COVID-19 commonly present with fever, cough, and shortness of breath [13,14]. COVID-19 is more likely to progress to severe disease in high-risk patients, including the elderly and those with comorbidities like diabetes and hypertension [15]. In severe cases, COVID-19 exhibits immune system evasion by inducing T-cell apoptosis and suppressing various pathogenic clearance mechanisms, leading to immune system overactivation and the overproduction of inflammatory cytokines [16]. This phenomenon, known as cytokine storm syndrome (CSS), is characterized by severe pneumonia, acute respiratory distress syndrome (ARDS) and eventual multi-organ failure [15].

Currently, there is no known cure for COVID-19 [15]. Several vaccines exist and are approved for use in humans; however, they remain only a prophylactic measure against severe manifestations of COVID-19 [5]. Inequity in vaccine access for lower-income countries is a serious global issue that prolongs the pandemic [5]. Persistent transmission causes the emergence of variants, which may weaken or evade vaccine-acquired immunity [6,7]. Several therapeutic agents have been explored for the treatment of COVID-19 [17] and among them, remdesivir (Veklury), a broadspectrum antiviral drug, has shown clinical promise due to its ability to inhibit SARS-CoV-2 and other coronaviruses both in in vitro and in vivo models [18-20]. It has gained full or conditional authorization in 50 countries [21]. Remdesivir prevents coronavirus replication when converted into the metabolite GS-441524 triphosphate by the action of esterases, phosphoramidases, and host-cell kinases, which inhibits viral RNA polymerase, causing premature polypeptide chain termination [22,23]. Although Beigel et al. [20] demonstrated how remdesivir lowers hospital discharge times of COVID-19 patients, its efficacy remains controversial and may be virtually indistinguishable from placebo in morbidity and mortality for severe cases of COVID-19 [20,24]. Thus, it has been proposed that combination approaches be explored to further enhance the desired therapeutic effects of remdesivir [20].

The use of immunoregulatory therapeutics in patients with severe COVID-19 has been considered, as dysregulated and hyper-activated inflammatory responses primarily contribute to disease-related mortality [15,25-28]. Present efforts to evaluate remdesivir in combination with immunomodulatory drugs, like baricitinib, a Janus kinase (JAK) inhibitor, may improve clinical outcomes [29,30].

Mesenchymal stem cells (MSCs) are multipotent stem cells that can differentiate into various cell types, regulate immune responses, induce tissue regeneration, and may be isolated from a multitude of sources, such as bone marrow and adipose tissue [31]. Numerous studies have demonstrated that adult MSCs can modulate different immune cells to regulate adaptive and innate immunity [19]. MSCs contribute to immunomodulation through paracrine secretion of soluble factors and anti-inflammatory cytokines, as well as cell-cell contact mechanisms [32], which reduces concentrations of pro-inflammatory cytokines like tumor necrosis factor-alpha (TNF- $\alpha$ ), interleukin (IL)-6, IL-8, IL-12, and interferon-gamma (IFN$\gamma$ ), limiting the occurrence of CSS [19]. In clinical settings, the safety profile of MSCs has been well-established [31]. Early-phase trials have demonstrated that administration of MSCs resolves critical COVID-19 symptoms by decreasing inflammatory markers (such as C-reactive protein (CRP), IL-6, IL-8, and TNF- $\alpha$ ), regenerating lung tissue through secretions of vascular endothelial growth factor (VEGF) and transforming growth factor- $\beta 1$ (TGF- $\beta 1$ ), and normalizing immune cell populations $[15,33]$.

In light of promising benefits of MSCs in treating COVID-19, we propose an investigation that will use allogeneic menstrual blood-derived stem cells (MenSCs) in combination with remdesivir to treat severe COVID-19. MenSCs are a novel source of stem cells derived from human menstrual fluid [34]. They express various classical MSC surface markers and octamer binding transcription factor 4 (OCT-4), an embryonic stem cell marker, and are negative for several hematopoietic stem cell markers [34,35]. MenSCs are cultured and passaged through containers and effectively differentiate into a variety of stem cells under appropriate conditions [35,36]. MenSCs have been shown to suppress immune dysregulation and promote tissue regeneration $[35,36]$. Interest in MenSCs has grown recently due to their advantages of being an abundant and continuous MSC source, ease of procurement via non-invasive procedure, high proliferative rate, low immunogenicity, low malignancy, and lack of ethical concerns compared to traditional sources $[35,36]$. Such an investigation may elucidate a novel and efficacious treatment for severe COVID-19, a disease in which few effective therapies exist currently, and may provide a steppingstone for increased clinical research into the use of MenSCs in treating other disease states and COVID-19 variants.

The overall objective of the study is to examine and evaluate the effect of remdesivir and MenSC therapy on resolving severe COVID-19 infection, in comparison to remdesivir alone, as a control. Remdesivir-MenSC combination therapy is expected to demonstrate an improvement in clinical efficacy in shortening hospitalization, lowering disease severity, and reducing mortality, and safety relative to treatment with remdesivir alone in patients hospitalized with severe COVID-19.

\section{Methods}

This study will be a randomized, double-blind, controlled clinical trial to evaluate the safety and efficacy of co-administration of remdesivir and MenSCs to treat hospitalized patients with severe COVID-19. This study will enroll approximately 400 male and female adults 
UNDERGRADUATE RESEARCH IN NATURAL AND CLINICAL SCIENCE AND TECHNOLOGY (URNCST) JOURNAL Read more URNCST Journal articles and submit your own today at: https://www.urncst.com

between 18-75 years old hospitalized with severe COVID19 and who meet all eligibility criteria.

\section{Procurement}

The following procedure for the procurement and preparation of MenSCs is adapted from Zhong et al. [37], although note that no gold-standard exists. Concerning donor selection, there will be strict adherence to the Health Canada Cells, Tissues, and Organs for Transplantation Regulations (CTO Regulations) concerning allogeneic cell products. All donors will be recruited at participating hospitals and health clinics in Canada. All donors must be non-smoking female volunteers aged 18-30 who provide signed consent to donate menstrual blood. In addition, all donors must return a negative reverse transcription polymerase chain reaction (RT-PCR) test for COVID-19, human immunodeficiency virus (HIV), human papillomavirus virus (HPV), and hepatitis B and C. Donors will then undergo a standard medical history and physical evaluation for cardiovascular disease, diabetes, and malignancy.

Menstrual blood collection tubes are to be treated with $0.2 \mathrm{~mL}$ amphotericin $\mathrm{B}, 0.1 \mathrm{~mL}$ ethylenediaminetetraacetic acid (EDTA), and $0.2 \mathrm{~mL}$ streptomycin/penicillin. Collection of menstrual blood is to be done by the donor: a sterile Diva cup is to be inserted into the vagina for $\leq 4$ hours on days 1-3 of the menstrual cycle [37,38].

Contents of Diva cups should be decanted into collection tubes and then centrifuged for 10 minutes at $600 \mathrm{~g}$. After removal of the supernatant and washing of the cell pellet with more PBS solution, cells are to be collected using sterile Cytiva Ficoll-Paque (Fisher Scientific, Portsmouth NH) liquid density gradient media $(1.078 \mathrm{~g} / \mathrm{mL})$.
The collected cells are to be plated in a T-75 flask with $25 \mathrm{~mL}$ of complete Dulbecco's Modified Eagle Medium (cDMEM). They will be cultured for 24 hours in a humidified atmosphere with $5 \% \mathrm{CO} 2$ at $37^{\circ} \mathrm{C}$. Adherent cells are to be washed off using PBS solution and $0.05 \%$ trypsin with EDTA. After centrifugation, cells will be washed with further cDMEM and plated in T-175 flasks. The contents were cultured for 5 days, and the subsequent cells are to be passed for 3-4 rounds.

To be considered viable for culturing and subsequent administration, the MenSCs must have an endotoxin concentration below 1.65 endotoxin units per $\mathrm{mL}$, measured using a chromogenic endotoxin detection assay kit (Fisher Scientific, Portsmouth NH). Additionally, the MenSCs must have morphology matching a fibroblastic shape and $>95 \%$ cell viability (as assessed using flow cytometry) and no bacterial contamination, assessed using a cell culture contamination detection kit (Fisher Scientific, Portsmouth $\mathrm{NH})$. MenSCs are to be cryopreserved in liquid nitrogen at $196^{\circ} \mathrm{C}$ prior to the trial period [39].

A Class II biosafety cabinet, located in an ISO Class 7 clean room, will be used to contain the collection tubes containing phosphate-buffered saline (PBS) solution.

\section{$\underline{\text { Eligibility }}$}

Study participants will be recruited to the trial at participating hospitals in Canada, where the duration of the data collection and study intervention period will take place. For a patient to be considered eligible to participate in the study, the criteria in Table 1 must be met. A patient who meets any criteria listed in Table 2 shall be excluded from participation in this study.

Table 1. Inclusion Criteria

\begin{tabular}{|l|l|}
\hline Criteria & Details \\
\hline Positive for COVID-19 & Subject RT-PCR must return positive for the presence of SARS-CoV-2. \\
\hline $\begin{array}{l}\text { Patient has "severe" } \\
\text { COVID-19 as per } \\
\text { National Institutes of } \\
\text { Health [52]. }\end{array}$ & $\begin{array}{l}\text { At least one of the following conditions must be met: } \\
\text {-Subject requires mechanical ventilation/supplemental oxygen; } \\
\text {-Oxygen saturation (measured with pulse oximetry) at } \leq 94 \% ; \\
\text {-Arterial partial pressure of oxygen to fraction of inspired oxygen ratio }<300 \mathrm{~mm} \text { Hg; } \\
\text {-Respiratory frequency }>30 \text { breaths per minute; or } \\
\text {-Pulmonary infiltrates }>50 \% \text { by imaging. }\end{array}$ \\
\hline Consent & $\begin{array}{l}\text { All subjects must provide informed written consent, including agreement to comply with all } \\
\text { study procedures and post-intervention visits. }\end{array}$ \\
\hline Age & $\begin{array}{l}\text { All subjects must be aged 18-75 and should weigh } \geq 40 \text { kg. Children and adolescents are } \\
\text { excluded from participation as clinical trials of remdesivir have generally excluded them and as } \\
\text { such, pediatric data is limited and warrants further safety research. The basis of the exclusion } \\
\text { comes from epidemiological data of COVID-19 which indicates an overwhelming burden of } \\
\text { severe disease in older adults, especially those with coexisting illness, whereas children have a } \\
\text { low incidence of severe disease, representing 1-2\% of total COVID-19 burden [1,20,53]. }\end{array}$ \\
\hline Female Subjects & \begin{tabular}{l} 
Female subjects must be willing to use prescribed contraceptives for the duration of the study. \\
\hline
\end{tabular}
\end{tabular}


UNDERGRADUATE RESEARCH IN NATURAL AND CLINICAL SCIENCE AND TECHNOLOGY (URNCST) JOURNAL

Read more URNCST Journal articles and submit your own today at: https://www.urncst.com

Table 2. Exclusion Criteria

\begin{tabular}{|l|}
\hline Presence of a malignant chronic disease within the past 5 years. \\
\hline Patient is participating in another clinical trial. \\
\hline Patient (or legally authorized representative) is unable to provide written consent. \\
\hline Patient is allergic to any drug used in the study. \\
\hline Patient is expected to die within 48 hours. \\
\hline Patient is afflicted with other pulmonary conditions and/or autoimmune diseases. \\
\hline Female patients are pregnant, nursing, or expecting. \\
\hline Patient tests positive for HIV, HPV, syphilis, or hepatitis B or C. \\
\hline Anticipated discharge from hospital within 72 hours on enrollment. \\
\hline Continuous use of immunosuppressive agents. \\
\hline Patient has undergone organ transplants in the past 6 months. \\
\hline History of illegal drug abuse. \\
\hline Patient has impaired renal function (estimated glomerular filtration rate (eGFR) $<30 \mathrm{~mL} / \mathrm{min})$. \\
\hline Alanine transaminase (ALT) or aspartate transaminase (AST) $>5$ times the normal upper limit \\
\hline
\end{tabular}

\section{Procedure}

Both control and treatment groups will receive standard of care for COVID-19 appropriate for a given patient's conditions. It is considered unethical to give a true placebo to patients with severe COVID-19 when standards for treating COVID-19 exist. The control group will receive only remdesivir using procedures adapted from Beigel et al [20]. The ambient vials of lyophilized remdesivir formulation are to be stored below $30^{\circ} \mathrm{C}$. The drug should be reconstituted and diluted prior to IV injection. Inactive ingredients include sulfobutylether $\beta$-cyclodextrin sodium (SBECD), and hydrochloric acid and/or sodium hydroxide and water for injection. The time period between reconstitution and administration of the remdesivir solution should not pass 4 hours (at room temperature) or 24 hours (at $2-8^{\circ} \mathrm{C}$ ) refrigeration.

The remdesivir regimen is adapted from Kalil et al. [29]. On Day 1 of the study, a $200 \mathrm{mg}$ loading dose of remdesivir should be administered intravenously, with $100 \mathrm{mg}$ followup doses for the next 9 days thereafter or until death/discharge. This dosage, from Kalil et al., is standard for adults weighing above $40 \mathrm{~kg}$ [29]. A matching saline solution placebo of equal dosage, schedule, and appearance to the MenSC treatment will accompany each dose of remdesivir.

The treatment group will receive both remdesivir and MenSCs. The remdesivir procedure and regimen will follow the same steps outlined previously. In accordance with Antebi et al., prior to administration of MenSCs, a 24-hour acclimatization period post-thawing is required for MSCs to regain full anti-inflammatory capabilities [39]. MenSCs should be injected intravenously in $100 \mathrm{~mL}$ of saline solution. The dosage is set at $6 \times 10^{6}$ MenSCs per $\mathrm{kg}$ of body weight (dosage adapted from clinical trial NCT04339660) [40]. MenSCs doses should be given on every alternate day starting at Day 1 until Day 9 or death/discharge.

$\underline{\text { Adverse Events }}$

Adverse events (AEs) are any unintended, unfavourable medical occurrence, such as a sign, symptom, or disease, temporally associated with the use of an investigational product, regardless of whether it is intervention-related [20]. A SAE is an AE that results in or has the potential to result in death, prolongation of existing hospitalization, or significant incapacity/persistent disruption in the ability to carry out normal life functions [20]. The evaluation and classification of AEs (see Table 3) will be based on the medical judgement of a licensed onsite investigator, including but not limited to physicians and nurse practitioners. AEs and SAEs will all be assessed for severity based on the Division of Acquired Immunodeficiency Syndrome (DAIDS) Table [41]. The protocol team will review blinded collections of $\mathrm{AE}$ and SAE data weekly and conduct unblinded ad hoc reviews if there are a significant number of unexpected AEs. An AE is deemed to be intervention-related if there is a temporal relationship between the intervention and the $\mathrm{AE}$, and the $\mathrm{AE}$ is known to occur with the intervention or there is reason to suggest a causal relationship exists. An AE is unrelated if there is no evidence of a causal relationship, or there is no temporal relationship, or an alternate cause has been identified. 
UNDERGRADUATE RESEARCH IN NATURAL AND CLINICAL SCIENCE AND TECHNOLOGY (URNCST) JOURNAL Read more URNCST Journal articles and submit your own today at: https://www.urncst.com

Table 3. DAIDS Table for Grading the Severity of Adult and Pediatric Adverse Events, corrected version 2.1

\begin{tabular}{|l|l|}
\hline Severity & Criteria \\
\hline Moderate (Grade 2) & $\begin{array}{l}\text { Events that are usually alleviated with additional specific } \\
\text { therapeutic intervention. The event interferes with usual activities of daily living and causes } \\
\text { discomfort, but poses no significant or permanent risk of harm to the research subject. }\end{array}$ \\
\hline Severe (Grade 3) & $\begin{array}{l}\text { Events that interrupt usual activities of daily living, or significantly affect clinical status, or } \\
\text { may require intensive therapeutic intervention. Severe events are usually incapacitating. }\end{array}$ \\
\hline Severe (Grade 4) & Events that are potentially life threatening \\
\hline Death (Grade 5) & All deaths related to an AE are to be classified as Grade 5. \\
\hline
\end{tabular}

\section{Study Timeline}

Subjects will be screened according to the eligibility criteria and recruited at Day -1 to 1 . This includes a detailed review of subject demographics and medical history, and a physical examination. Baseline assessments (e.g., ordinal scale, NEWS2) and laboratory testing (e.g. oropharyngeal swab, blood) will be conducted on Day 1, prior to randomization. Participants are block-randomized, stratified by ordinal score, sex, race, body weight, ethnic group, duration of symptoms before randomization (measured as $\leq 10$ days or $>10$ days), presence of coexisting conditions, vaccination status (unvaccinated, partial-vaccination, or fullvaccination), and assigned in a 1:1 ratio to either receive remdesivir-MenSC combination, or remdesivir alone (control group). The control or treatment intervention will be administered on Day 1. Subjects will be assessed for 29 days. Subjects will be assessed daily on ordinal scale score of clinical status (Table 4) and NEWS2 score (a measure of disease severity; see Table 6) and will undergo a series of various clinical efficacy, safety, and laboratory assessments. A participant's total NEWS2 score (which can have a maximum possible value of 22) is calculated by summing the score of several physiological parameters (including respiratory rate, blood oxygen saturation, supplemental oxygen, systolic blood pressure, pulse, consciousness, and temperature). Blood and serum sample collection and oropharyngeal (OP) swabs will occur on Day 3, 5, 8, 11, 15, 22 , and 29, if able to return to clinic or if still hospitalized. Patients are followed monthly for up to 12 months to monitor safety.

\section{Primary Endpoints}

This study will use multiple primary endpoints to assess efficacy of remdesivir-MenSC combination therapy. One primary endpoint is time of recovery (by Day 29), measured in days after enrollment. A subject is considered to have recovered if they have an ordinal score of 1,2 , or 3 and if they test negative for 2 consecutive RT-PCR tests for SARS-CoV-2. Additionally, immune response will be gauged by the change in the concentration of a group of cytokines (IL-1 $\beta$, IL- 2 , TNF- $\alpha$, IFN- $\gamma$, IL-4, IL-6, IL-10) from baseline (on Day 1, before control or MenSC intervention) to Day 15. The group of cytokines are coprimary endpoints.

Table 4. 8-point Ordinal Scale for Clinical Status (using categories defined by Beigel et al.) [20]

\begin{tabular}{|l|l|}
\hline Score & Criteria $(\mathbf{1}=$ best, healthy; $\mathbf{8}=$ worst $)$ \\
\hline 1 & Not hospitalized, no limitations on activities. \\
\hline 2 & Not hospitalized, limitation on activities. \\
\hline 3 & Hospitalized, not requiring supplemental oxygen, no longer requiring ongoing medical care. \\
\hline 4 & Hospitalized, not requiring supplemental oxygen, requiring ongoing medical care. \\
\hline 5 & Hospitalized, requiring supplemental oxygen. \\
\hline 6 & Hospitalized, on non-invasive ventilation or high flow oxygen devices. \\
\hline 7 & Hospitalized, on invasive mechanical ventilation/extracorporeal membrane oxygenation (ECMO). \\
\hline 8 & Death. \\
\hline
\end{tabular}


UNDERGRADUATE RESEARCH IN NATURAL AND CLINICAL SCIENCE AND TECHNOLOGY (URNCST) JOURNAL
Read more URNCST Journal articles and submit your own today at: $\underline{\text { https://www.urncst.com }}$

Secondary Endpoints

Table 5 summarizes the key secondary endpoint measures of the study.

Table 5. Secondary Endpoints

\begin{tabular}{|l|l|}
\hline Objectives & Endpoints (Outcome measures) \\
\hline Disease severity & $\begin{array}{l}\text { The National Early Warning Score 2 (NEWS2) score is used in emergency medicine to assess the } \\
\text { severity of disease in a patient. It has been validated by Myrstad et al. and others to strongly predict } \\
\text { in-hospital mortality scores from COVID-19 [53,54]. The change in NEWS2 score from baseline } \\
\text { (Day 1) to Days 3, 5, 8, 11, 15, 22, and 29. }\end{array}$ \\
\hline Pulmonary function. & $\begin{array}{l}\text { Change in blood oxygen saturation, measured using a pulse oximeter, from baseline (Day 1) to Days } \\
3,5,8,11,15,22, \text { and 29. }\end{array}$ \\
\hline Hospitalization & Duration of hospitalization up to Day 29 \\
\hline Mortality & $\begin{array}{l}\text { 14-day mortality; } \\
\text { 29-day mortality }\end{array}$ \\
\hline Virologic efficacy. & $\begin{array}{l}\text { Percentage of subjects with SARS-CoV-2 present in OP swab sample on Days 3, 5, 8, 11, 15, and 29 } \\
\text { (from Beigel et al.) [20]. Change evaluated from baseline (Day 1) to Days 3, 5, 8, 11, 15, 22, and 29. }\end{array}$ \\
\hline Safety & $\begin{array}{l}\text { Cumulative incidence of SAEs; } \\
\text { Cumulative incidence of Grade 3 and 4 AEs }\end{array}$ \\
\hline General indicators. & $\begin{array}{l}\text { Changes in white cell count, hemoglobin, platelets, creatinine, glucose, total bilirubin, CRP, ferritin, } \\
\text { prothrombin time, ALT, and AST from Day 1 (baseline) to Days 3, 5, 8, 11, 15, 22, and 29. }\end{array}$ \\
\hline
\end{tabular}

Table 6. The NEWS2 Scoring Table. CVPU refers to new confusion (C), or arousable only to voice (V), or pain (P), or unresponsive (U). Reproduced from: Royal College of Physicians. National Early Warning Score (NEWS) 2: Standardising the assessment of acute-illness severity in the NHS. Updated report of a working party. London: RCP, 2017 [42].

Chart 1: The NEWS scoring system

\begin{tabular}{|c|c|c|c|c|c|c|c|}
\hline $\begin{array}{l}\text { Physiological } \\
\text { parameter }\end{array}$ & 3 & 2 & 1 & $\begin{array}{c}\text { Score } \\
0\end{array}$ & 1 & 2 & 3 \\
\hline $\begin{array}{l}\text { Respiration rate } \\
\text { (per minute) }\end{array}$ & $\leq 8$ & & $9-11$ & $12-20$ & & $21-24$ & $\geq 25$ \\
\hline $\mathrm{SpO}_{2}$ Scale $1(\%)$ & $\leq 91$ & $92-93$ & $94-95$ & $\geq 96$ & & & \\
\hline $\mathrm{SpO}_{2}$ Scale $2(\%)$ & $\leq 83$ & $84-85$ & $86-87$ & $\begin{aligned} & 88-92 \\
\geq & 93 \text { on air }\end{aligned}$ & $\begin{array}{c}\text { 93-94 on } \\
\text { oxygen }\end{array}$ & $\begin{array}{c}\text { 95-96 on } \\
\text { oxygen }\end{array}$ & $\begin{array}{l}\geq 97 \text { on } \\
\text { oxygen }\end{array}$ \\
\hline Air or oxygen? & & Oxygen & & Air & & & \\
\hline $\begin{array}{l}\text { Systolic blood } \\
\text { pressure (mmHg) }\end{array}$ & $\leq 90$ & $91-100$ & $101-110$ & $111-219$ & & & $\geq 220$ \\
\hline Pulse (per minute) & $\leq 40$ & & $41-50$ & $51-90$ & $91-110$ & $111-130$ & $\geq 131$ \\
\hline Consciousness & & & & Alert & & & CVPU \\
\hline Temperature $\left({ }^{\circ} \mathrm{C}\right)$ & $\leq 35.0$ & & $35.1-36.0$ & $36.1-38.0$ & $38.1-39.0$ & $\geq 39.1$ & \\
\hline
\end{tabular}


UNDERGRADUATE RESEARCH IN NATURAL AND CLINICAL SCIENCE AND TECHNOLOGY (URNCST) JOURNAL Read more URNCST Journal articles and submit your own today at: $\underline{\text { https://www.urncst.com }}$

\section{Statistical Analysis}

At baseline, groups were compared for equality using t-tests or Chi-squared when appropriate. A stratified logrank test will be conducted to compare the time of recovery of the treatment group with the control group, with stratification by disease severity (baseline ordinal score) [20]. For time-to-recovery analyses, data of patients who did not recover or who die by Day 29 will be censored. Two-sample repeated measures ANOVA will be used to compare a given cytokine's levels between the treatment group and the control group from Day 1 (baseline) to Days $3,5,8,11,15,22$, and 29 , with post hoc comparisons.

Statistical analyses of secondary endpoints will also be conducted. Proportional odds model will compare the likelihood of decrease in NEWS2 score (from baseline to Day 15) between treatment and control groups, with stratification by baseline ordinal score [20]. Two-way repeated measures ANOVA will be used to compare blood oxygen saturation from baseline to Days 3, 5, 8, 11, 22, and 29 between treatment and control groups. Kaplan-Meier estimates of mortality at 14 days and at 29 days will be generated. Two-way repeated measures ANOVAs will be used as appropriate to compare other general indicators' levels (as listed in Table 5) before and after MenSC intervention in the treatment group (from baseline to Days $3,5,8,11,15,22$, and 29) to that indicator's level before and after control intervention in the control group (from baseline to Days 3, 5, 8, 11, 15, 22, and 29). Finally, Barnard's exact test will be conducted to compare frequency of patients who would have experienced SAEs and Grade 3 or 4 AEs between treatment and control groups [20].

Safety endpoints will be presented as a percentage. Significance of data analysis will be evaluated with Student's $t$-test. A $p$ value of $<0.05$ will be deemed statistically significant. Proportional difference with $95 \%$ confidence intervals will be used when comparing study arms.

\section{Anticipated Results}

Overall, it is hypothesized that remdesivir-MenSC combination therapy will show better prognosis than the control group.

It is expected that the treatment group will have a shorter time of recovery than the control group. Given MSCs' immunomodulatory properties [19,32], it is expected that the treatment group will show a greater reduction in pro-inflammatory cytokine (including IL-1 $\beta$, IL-2, IL-6, TNF- $\alpha$, IFN- $\gamma$ ) concentrations and a greater increase in anti-inflammatory cytokine (including IL-4, IL10) concentrations [43], as compared to the control group. For the combination therapy to be considered efficacious, either the time of recovery must be significantly different between treatment and control groups, or the changes in concentrations of all co-primary cytokine endpoints must be significantly different between treatment and control groups. The recovery time of patients with severe COVID-19 is expected to be lowered and improved when administered the combination treatment of MenSCs and remdesivir, compared to treatment with remdesivir alone.

Regarding secondary endpoints, the results are expected to demonstrate a greater decrease in NEWS2 score, greater increase in blood oxygen saturation, and a lower 14-day and 29-day mortality in the treatment group, as compared to the control group. With the other general indicators, we expect the serum levels of the general indicators to approach normal ranges to a greater degree in the treatment group than the control group. The combination treatment is expected to show a greater safety profile than remdesivir treatment alone by lowering the frequency of SAEs and Grade 3/4 AEs.

\section{Discussion}

Based on current literature, the remdesivir-MenSC combination treatment group is expected to have shorter time of recovery and greater decrease in pro-inflammatory cytokine levels, as compared to the control group.

There has been some limited phase 1 and phase 2 trials conducted on umbilical cord-derived MSC (UC-MSC) infusion in patients with severe COVID-19, and many trials demonstrate encouraging results (e.g., patients having decreased cytokine levels, significantly increased lymphocyte count) [44]. However, there are limited COVID19-related studies evaluating MSC infusion from non-UCMSC sources, and even fewer specifically involving MenSCs [44-46]. In general, it was found that patients receiving MSC infusion with standard treatment had better mortality outcomes, faster recovery of oxygenation levels, and reduced lung inflammation (as compared to patients receiving standard treatment alone) [29,44-46]. Kalil et al. found that baricitinib plus remdesivir was superior to remdesivir alone in reducing recovery time for moderate and severe COVID19 patients [29]. Patients receiving high-flow oxygen or noninvasive ventilation at baseline recovered 8 days earlier on average when taking combination treatment, compared to remdesivir alone [29]. As both MenSCs and baricitinib function as immunomodulators, it is expected that the recovery time will be improved in this study. RemdesivirMenSC combination is expected to show a greater safety profile than the control group by lowering the frequency of SAEs and Grade 3 or 4 AEs. Kalil et al. found a 5\% improvement in SAE incidence from $21 \%$ (control) to $16 \%$ (combination) [29].

When compared to traditional MSC sources, the procurement of MenSCs is more efficient, non-invasive, cheap, plentiful, and lacking in ethical concern [35]. Furthermore, MenSCs have higher proliferation rates and lower malignancy [15]. MSCs are immune privileged (i.e., they avoid normal processes involved in allogeneic rejection), allowing for transplantation with little fear of rejection [15]. Hence, MenSCs are promising contenders with MSCs from bone marrow, umbilical cords, and other 
UNDERGRADUATE RESEARCH IN NATURAL AND CLINICAL SCIENCE AND TECHNOLOGY (URNCST) JOURNAL Read more URNCST Journal articles and submit your own today at: https://www.urncst.com

more logistically demanding sources. Therefore, this study can facilitate a larger sample size than otherwise.

Another strength of this study is the use of IV administration of MenSCs. Pulmonary entrapment refers to the tendency for intravenously injected MSCs to accumulate in the lungs. With IV infusion, more than $80 \%$ of all MSCs are entrapped in the lungs [47]. This makes the therapeutic effects of MenSCs concentrate in the lungs, leading to easier detection.

A key weakness associated with this study is failure to account for the effects of MenSC donor heterogeneity. The current literature lacks any systematic assessment of an appropriate donor range. MenSCs exhibit various stages which differ in their therapeutic ability [35]. In addition, donors vary based on epidemiological background, endocrine changes, age, and contraceptive/hormone use. The dosage of MenSCs for human treatment vary greatly from those used in animal models [37,48-50]. As such, standardized dosage values should be established for future clinical use. Additionally, as it is unethical to not provide standard care to patients, the study is limited by the lack of a true placebo.

Optimal MenSC cell expansion and preparation procedures are still undecided in the literature [35]. In a study by Matthay et al., it was found that the clinical viability of MSCs varied across similar preparation techniques in different sites [51]. The quality of MenSC samples is also subject to variability as there is no goldstandard on molecular markers for an ideal batch of MenSCs for clinical use [35]. Further investigation into the effects of different cell expansion and preparation procedures on patient outcomes is therefore necessary.

\section{Conclusions}

The intent of this protocol is to investigate the clinical feasibility of MenSCs in patients with severe COVID-19 in conjunction with remdesivir. This is to improve the utility of MenSCs in pulmonary conditions, and to ameliorate existing COVID-19 therapies.

MenSCs present a superior alternative to traditional MSC sources. In addition to the advantages, MenSCs can likely facilitate large-scale growth without substantial mutagenesis and display fewer mutations (as compared to other MSC sources), with Chen et al. reporting at least 20 passages without karyotypic abnormalities [35]. When delivered intravenously, a majority of MenSCs will remain in the lungs [15]. For these reasons, MenSCs present a promising novel clinical option in treating pulmonary diseases.

Chen et al. noted that the literature contains no data concerning the duration of therapeutic effects, nor any guarantee of long-term safety [35]. In addition, the detailed mechanism of action and long-term side effects in foreign bodies are unknown [35]. Further, research is required to verify optimal dosage, donor age, and administration route [35].
As more concerning COVID-19 variants emerge, particularly those that show potential to be more resilient against vaccines, it is crucial to investigate novel treatment options [12].

\section{List of Abbreviations Used}

AE: adverse event

ALT: alanine transaminase

ANOVA: analysis of variance

ARDS: acute respiratory distress syndrome

AST: aspartate transaminase

cDMEM: complete dulbecco's modified eagle medium

CFR: code of federal regulations

COVID-19: coronavirus disease 2019

CRP: c-reactive protein

CSS: cytokine storm syndrome

CTO: cells, tissues, and organs

DAIDS: division of acquired immunodeficiency syndrome

ECMO: extracorporeal membrane oxygenation

EDTA: ethylenediaminetetraacetic acid

eGFR: estimated glomerular filtration rate

ELISA: enzyme-linked immunosorbent assay

HIV: human immunodeficiency virus

HPV: human papillomavirus

IFN- $\gamma$ : interferon-gamma

IL: interleukin

IV: intravenous

JAK: janus kinase

MenSC: menstrual blood-derived stem cell

MSC: mesenchymal stem cell

mRNA: messenger ribonucleic acid

NEWS2: national early warning score 2

NIH: national institutes of health

NSAIDS: nonsteroidal anti-inflammatory drugs

OCT-4: octamer binding transcription factor 4

OP: oropharyngeal

PCR: polymerase chain reaction

PHEIC: public health emergency of international concern

RNA: ribonucleic acid

SAE: serious adverse event

SARS-CoV-1: severe acute respiratory syndrome

coronavirus 1

SARS-CoV-2: Severe acute respiratory syndrome

coronavirus 2

SBECD: sulfobutylether $\beta$-cyclodextrin sodium

TGF- $\beta 1$ : transforming growth factor- $\beta 1$

TNF- $\alpha$ : tumor necrosis factor-alpha

UC-MSC: umbilical cord-derived mesenchymal stem cell

VEGF: vascular endothelial growth factor

VOC: variant of concern

VOI: variant of interest

WHO: world health organization

\section{Conflicts of Interest}

The authors declare that they have no conflict of interests. 
UNDERGRADUATE RESEARCH IN NATURAL AND CLINICAL SCIENCE AND TECHNOLOGY (URNCST) JOURNAL Read more URNCST Journal articles and submit your own today at: https://www.urncst.com

\section{Ethics Approval and/or Participant Consent}

This study will require ethics approval and participant consent and will be conducted in accordance with principles set forth by the Tri-Council Policy Statement: Ethical Conduct for Research Involving Humans, the International Conference on Harmonization Good Clinical Practice Guidelines (ICH-GCP), Health Canada CTO regulations, and the requirements of the US Department of Health and Human Services, as set out in the Federal Policy for the Protection of Human Subjects, 45CFR Part 46, sub-part A. The Health Canada and Public Health Agency of Canada Research Ethics Board (REB) and other authorized REBs would review and approve this protocol and all associated documents, including informed consent documents, recruitment material, and handouts for donors and subjects, prior to the screening and enrollment of donors and subjects. REB reviews shall adhere to regulations and policies outlined above and all relevant federal, provincial, and municipal regulations and policies.

\section{Authors' Contributions}

AJWC: made contributions to the design of the study, drafted the manuscript, revised the manuscript critically, and gave final approval of the version to be published.

DJ: made contributions to the design of the study, drafted the manuscript, revised the manuscript critically, and gave final approval of the version to be published.

HL: made contributions to the design of the study, drafted the manuscript, revised the manuscript critically, and gave final approval of the version to be published.

\section{Acknowledgements}

None.

\section{Funding}

This study was not funded.

\section{References}

[1] Guan W, Ni Z, Hu Y, Liang W, Ou C, He J, et al. Clinical characteristics of coronavirus disease 2019 in China. The New England Journal of Medicine. 2020 Apr 30;382(18):1708-20. https://doi.org/10.1056/ NEJMoa2002032

[2] World Health Organization [Internet]. Coronavirus disease (COVID-19) weekly epidemiological update and weekly operational update. [cited 2021 Aug 20]. Available from: https://www.who.int/emergencies/ diseases/novel-coronavirus-2019/situation-reports

[3] World Health Organization [Internet]. WHO coronavirus (COVID-19) dashboard. [cited 2021 Oct 17]. Available from: https://covid19. who.int/
[4] Coronaviridae Study Group of the International Committee on Taxonomy of Viruses. The species severe acute respiratory syndrome-related coronavirus: Classifying 2019-nCoV and naming it SARS-CoV-2. Nature Microbiology. 2020 Mar 2;5(4):536-44. https://doi.org/10.1038/s41564-020-0695-Z

[5] Fontanet A, Autran B, Lina B, Kieny MP, Karim SS, Sridhar D. SARS-CoV-2 variants and ending the COVID-19 pandemic. The Lancet. 2021 Mar 13;397(10278):952-4. https://doi.org/10.1016/S01406736(21)00370-6

[6] Lopez Bernal J, Andrews N, Gower C, Gallagher E, Simmons R, Thelwall S, et al. Effectiveness of Covid-19 vaccines against the B. 1.617. 2 (Delta) variant. New England Journal of Medicine. 2021 Aug 12; 385(7):58594. https://doi.org/10.1056/NEJMoa2108891

[7] Mascola JR, Graham BS, Fauci AS. SARS-CoV-2 viral variants-Tackling a moving target. Journal of the American Medical Association. $2021 \mathrm{Feb}$ 11;325(13):1261-2. https://doi.org/10.1001/jama.2021 .2088

[8] Lauring AS, Malani PN. Variants of SARS-CoV-2. Journal of the American Medical Association. 2021 Aug 13;326(9):880. https://doi.org/10.1001/jama.2021.14181

[9] Government of the UK [Internet]. Variants: Distribution of case data, 20 May 2021. [cited 2021 October 13]. Available from: https://www.gov.uk/ government/publications/covid-19-variantsgenomically-confirmed-case-numbers/variantsdistribution-of-cases-data

[10] del Rio C, Malani PN, Omer SB. Confronting the delta variant of SARS-CoV-2, summer 2021. Journal of the American Medical Association. 2021 Aug 18;326(11):1001-1002. https://doi.org/10.1001/jama .2021 .14811

[11] Government of Canada [Internet]. COVID-19 daily epidemiology update. [cited 2021 Aug 23]. Available from: https://health-infobase.canada.ca/covid-19/ epidemiological-summary-covid-19-cases.html

[12] Mahase E. Covid-19: How many variants are there, and what do we know about them? British Medical Journal. 2021 Aug 19;374:1971. https://doi.org/ 10.1136/bmj.n1971

[13] Chen N, Zhou M, Dong X, Qu J, Gong F, Han Y, et al. Epidemiological and clinical characteristics of 99 cases of 2019 novel coronavirus pneumonia in Wuhan, China: A descriptive study. The Lancet. 2020 Feb 15;395(10223):507-13. https://doi.org/10.1016/S01406736(20)30211-7

[14] Huang L, Ma W, Ma Y, Feng D, Chen H, Cai B. Exosomes in mesenchymal stem cells, a new therapeutic strategy for cardiovascular diseases?. International Journal of Biological Sciences. 2015;11(2):238-45. https://doi.org/10.7150/ijbs.10725 
UNDERGRADUATE RESEARCH IN NATURAL AND CLINICAL SCIENCE AND TECHNOLOGY (URNCST) JOURNAL

Read more URNCST Journal articles and submit your own today at: https://www.urncst.com

[15] Durand N, Mallea J, Zubair AC. Insights into the use of mesenchymal stem cells in COVID-19 mediated acute respiratory failure. Nature Partner Journal of Regenerative Medicine. 2020 Oct 26;5(1):1-9. https://doi.org/10.1038/s41536-020-00105-Z

[16] Felsenstein S, Herbert JA, McNamara PS, Hedrich CM. COVID-19: Immunology and treatment options. Clinical Immunology. 2020 Jun 1;215:108448. https://doi.org/10.1016/j.clim.2020.108448

[17] Fauci AS, Lane HC, Redfield RR. Covid-19Navigating the uncharted. The New England Journal of Medicine. 2020 Mar 26;382(13):1268-9. https://doi.org/10.1056/NEJMe2002387

[18] Brown AJ, Won JJ, Graham RL, Dinnon III KH, Sims AC, Feng JY, et al. Broad spectrum antiviral remdesivir inhibits human endemic and zoonotic deltacoronaviruses with a highly divergent RNA dependent RNA polymerase. Antiviral Research. 2019 Sep 1;169:104541. https://doi.org/10.1016/j.antiviral .2019 .104541

[19] Basiri A, Pazhouhnia Z, Beheshtizadeh N, Hoseinpour M, Saghazadeh A, Rezaei N. Regenerative medicine in COVID-19 treatment: Real opportunities and range of promises. Stem Cell Reviews and Reports. 2021 Feb;17(1):163-75. https://doi.org/10.1007/s12015-020$\underline{09994-5}$

[20] Beigel JH, Tomashek KM, Dodd LE, Mehta AK, Zingman BS, Kalil AC, et al. Remdesivir for the treatment of covid-19-final report. The New England Journal of Medicine. 2020 Oct 8;383(19):1813-26. https://doi.org/10.1056/NEJMoa2007764

[21] Gilead [Internet]. Veklury® Global Marketing Authorization Status. [cited 2021 Jul 27]. Available from: https://www.gilead.com/purpose/advancingglobal-health/covid-19/veklury-global-marketingauthorization

[22] Eastman RT, Roth JS, Brimacombe KR, Simeonov A, Shen M, Patnaik S, et al. Remdesivir: A review of its discovery and development leading to emergency use authorization for treatment of COVID-19. American Chemical Society Central Science. 2020 May 27;6(5): 672-83. https://doi.org/10.1021/acscentsci.0c00489

[23] Kokic G, Hillen HS, Tegunov D, Dienemann C, Seitz F, Schmitzova J, et al. Mechanism of SARS-CoV-2 polymerase stalling by remdesivir. Nature Communications. 2021 Jan 12;12(1):279. https://doi.org/10.1038/s41467-020-20542-0

[24] Magro G. COVID-19: Review on latest available drugs and therapies against SARS-CoV-2. Coagulation and inflammation cross-talking. Virus Research. 2020 Sep 1;286:198070. https://doi.org/10.1016/j.virusres.2020 .198070
[25] Conti P, Ronconi G, Caraffa AL, Gallenga CE, Ross R, Frydas I, et al. Induction of pro-inflammatory cytokines (IL-1 and IL-6) and lung inflammation by coronavirus-19 (CoV-19 or SARS-CoV-2): Antiinflammatory strategies. Journal of Biological Regulators and Homeostatic Agents. 2020 Mar 1;34(2):1. https://doi.org/10.23812/CONTI-E

[26] Shang L, Zhao J, Hu Y, Du R, Cao B. On the use of corticosteroids for 2019-nCoV pneumonia. The Lancet. 2020 Feb 29;395(10225):683-4. https://doi.org/ 10.1016/S0140-6736(20)30361-5

[27] Zhang Y, Ding J, Ren S, Wang W, Yang Y, Li S, et al. Intravenous infusion of human umbilical cord Wharton's jelly-derived mesenchymal stem cells as a potential treatment for patients with COVID-19 pneumonia. Stem Cell Research Therapy. 2020 May 27;11(1):1-6. https://doi.org/10.1186/s13287-020-01725-4

[28] Deng Y, Liu W, Liu K, Fang YY, Shang J, Zhou L, et al. Clinical characteristics of fatal and recovered cases of coronavirus disease 2019 in Wuhan, China: A retrospective study. Chinese Medical Journal. 2020 Jun 5;133(11):1261. https://doi.org/10.1097/CM9.00000000 00000824

[29] Kalil AC, Patterson TF, Mehta AK, Tomashek KM, Wolfe CR, Ghazaryan V, et al. Baricitinib plus remdesivir for hospitalized adults with covid-19. New England Journal of Medicine. 2021 Mar 4;384(9):795807. https://doi.org/10.1056/NEJMoa2031994

[30] Mehta P, McAuley DF, Brown M, Sanchez E, Tattersall RS, Manson JJ. COVID-19: Consider cytokine storm syndromes and immunosuppression. The Lancet. 2020 Mar 28;395(10229):1033-4. https://doi.org/10.1016/S0140-6736(20)30628-0

[31] Gao F, Chiu SM, Motan DA, Zhang Z, Chen L, Ji HL, et al. Mesenchymal stem cells and immunomodulation: Current status and future prospects. Cell Death \& Disease. 2016 Jan;7(1):e2062. https://doi.org/10.1038/ cddis.2015.327

[32] Gebler A, Zabel O, Seliger B. The immunomodulatory capacity of mesenchymal stem cells. Trends in Molecular Medicine. 2012 Feb 1;18(2):128-34. https://doi.org/10.1016/j.molmed.2011.10.004

[33] Leng Z, Zhu R, Hou W, Feng Y, Yang Y, Han Q, et al. Transplantation of ACE2- mesenchymal stem cells improves the outcome of patients with COVID-19 pneumonia. Aging Disease. 2020;11(2):216-28. https://doi.org/10.14336/AD.2020.0228

[34] Zhao X, Zhang Y. Mesenchymal stem cells represent a potential therapeutic option for coronavirus disease 2019-related acute respiratory distress syndrome. Engineering (Beijing, China). 2020 Oct;6(10):1073-75. https://doi.org/10.1016/j.eng.2020.05.015 
UNDERGRADUATE RESEARCH IN NATURAL AND CLINICAL SCIENCE AND TECHNOLOGY (URNCST) JOURNAL Read more URNCST Journal articles and submit your own today at: https://www.urncst.com

[35] Chen L, Qu J, Cheng T, Chen X, Xiang C. Menstrual blood-derived stem cells: Toward therapeutic mechanisms, novel strategies, and future perspectives in the treatment of diseases. Stem Cell Research \& Therapy. 2019 Dec;10(1):1-12. https://doi.org/10.1186/ s13287-019-1503-7

[36] Lv H, Hu Y, Cui Z, Jia H. Human menstrual blood: A renewable and sustainable source of stem cells for regenerative medicine. Stem Cell Research \& Therapy. 2018 Dec;9(1):325. https://doi.org/10.1186/s13287018-1067-y

[37] Zhong Z, Patel AN, Ichim TE, Riordan NH, Wang H, Min W-P, et al. Feasibility investigation of allogeneic endometrial regenerative cells. Journal of Translational Medicine. 2009 Feb 20;7:15. https://doi.org/ 10.1186/1479-5876-7-15

[38] Borlongan C V., Kaneko Y, Maki M, Yu S-J, Ali M, Allickson JG, et al. Menstrual blood cells display stem cell-like phenotypic markers and exert neuroprotection following transplantation in experimental stroke. Stem Cells and Development. 2010 Apr 7;19(4):439-51. https://doi.org/10.1089/scd.2009.0340

[39] Antebi B, Asher AM, Rodriguez LA, Moore RK, Mohammadipoor A, Cancio LC. Cryopreserved mesenchymal stem cells regain functional potency following a 24-h acclimation period. Journal of Translational Medicine. 2019 Aug 29;17(1):297. https://doi.org/10.1186/s12967-019-2038-5

[40] ClinicalTrials.gov [Internet]. Bethesda (MD): National library of medicine (US). 2000 Feb 29. Identifier NCT04339660, clinical research of human mesenchymal stem cells in the treatment of COVID-19 pneumonia. [cited 2021 Jun 27]. Available from: https://clinicaltrials.gov/ct2/show/NCT04339660

[41] U.S. Department of Health and Human Services, National Institutes of Health, National Institute of Allergy and Infectious Diseases, Division of AIDS. Division of AIDS (DAIDS) table for grading the severity of adult and pediatric adverse events, corrected version 2.1 [Internet]. Besthesda. U.S. Department of Health and Human Services; 2017 [cited 2021 Jul 15]. Available from: https://rsc.niaid.nih.gov/sites/default/ files/daidsgradingcorrectedv21.pdf

[42] Royal College of Physicians. National early warning score (NEWS) 2: Standardising the assessment of acute-illness severity in the NHS [Internet]. Updated report of a working party. London: RCP, 2017. https://www.rcplondon.ac.uk/file/8636/download

[43] Song N, Wakimoto H, Rossignoli F, Bhere D, Ciccocioppo R, Chen K-S, et al. Mesenchymal stem cell immunomodulation: In pursuit of controlling COVID-19 related cytokine storm. Stem Cells. 2021 Mar 7;39(6):707-22. https://doi.org/10.1002/stem.3354
[44] Sharma D, Zhao F. Updates on clinical trials evaluating the regenerative potential of allogenic mesenchymal stem cells in COVID-19. Nature Partner Journal of Regenerative Medicine. 2021 Jun 30;6(1):1-11. https://doi.org/10.1038/s41536-021-00147-X

[45] Xu X, Jiang W, Chen L, Xu Z, Zhang Q, Zhu M, Ye P, Li H, Yu L, Zhou X, Zhou C. Evaluation of the safety and efficacy of using human menstrual blood-derived mesenchymal stromal cells in treating severe and critically ill COVID-19 patients: An exploratory clinical trial. Clinical and Translational Medicine. 2021 Feb;11(2):e297. https://doi.org/10.1002/ctm2.297

[46] Lu J, Xie ZY, Zhu DH, Li LJ. Human menstrual bloodderived stem cells as immunoregulatory therapy in COVID-19: A case report and review of the literature. World Journal of Clinical Cases. 2021 Mar 6;9(7):170513. https://doi.org/10.12998/wjcc.v9.i7.1705

[47] Wang S, Guo L, Ge J, Yu L, Cai T, Tian R, et al. Excess integrins cause lung entrapment of mesenchymal stem cells. Stem Cells. 2015 Nov;33(11):3315-26. https://doi.org/10.1002/stem.2087

[48] Cui CH, Uyama T, Miyado K, Terai M, Kyo S, Kiyono $\mathrm{T}$, et al. Menstrual blood-derived cells confer human dystrophin expression in the murine model of duchenne muscular dystrophy via cell fusion and myogenic transdifferentiation. Molecular Biology of the Cell. 2007 May;18(5):1586-94. https://doi.org/10.1091/mbc.e0609-0872

[49] Wu Q, Wang Q, Li Z, Li X, Zang J, Wang Z, et al. Human menstrual blood-derived stem cells promote functional recovery in a rat spinal cord hemisection model. Cell Death \& Disease. 2018 Aug 29;9(9):882. https://doi.org/10.1038/s41419-018-0847-8

[50] Tan J, Li P, Wang Q, Li Y, Li X, Zhao D, et al. Autologous menstrual blood-derived stromal cells transplantation for severe Asherman's syndrome. Human Reproduction. 2016 Dec 1;31(12):2723-9. https://doi.org/10.1093/humrep/dew235

[51] Matthay MA, Calfee CS, Zhuo H, Thompson BT, Wilson JG, Levitt JE, et al. Treatment with allogeneic mesenchymal stromal cells for moderate to severe acute respiratory distress syndrome (START study): A randomised phase $2 \mathrm{a}$ safety trial. The Lancet Respiratory Medicine. 2019 Feb 1;7(2):154-62. https://doi.org/10.1016/s2213-2600(18)30418-1

[52] Clinical spectrum of SARS-CoV-2 infection [Internet]. NIH. [cited 2021 Jul 16]. Available from: https://www.covid19treatmentguidelines.nih.gov/overv iew/clinical-spectrum/

[53]Zhou B, Yuan Y, Wang S, Zhang Z, Yang M, Deng X, et al. Risk profiles of severe illness in children with COVID-19: A meta-analysis of individual patients. Pediatric Research. 2021 Mar 22;1-6. https://doi.org/10.1038/s41390-021-01429-2 
UNDERGRADUATE RESEARCH IN NATURAL AND CLINICAL SCIENCE AND TECHNOLOGY (URNCST) JOURNAL Read more URNCST Journal articles and submit your own today at: https://www.urncst.com

[54] Myrstad M, Ihle-Hansen H, Tveita AA, Andersen EL, Nygård S, Tveit A, et al. National Early Warning Score 2 (NEWS2) on admission predicts severe disease and inhospital mortality from Covid-19- A prospective cohort study. Scandinavian Journal of Trauma, Resuscitation and Emergency Medicine. 2020 Dec;28(1):66 https://doi.org/10.1186/s13049-020-00764-3

\section{Article Information}

Managing Editor: Jeremy Y. Ng

Peer Reviewers: Vanessa Susevski, Jennifer Sarah Williams

Article Dates: Received Aug 25 21; Accepted Jan 05 21; Published Mar 0222

\section{Citation}

Please cite this article as follows:

Cao AJW, Jeyaraj D, Liu H. Co-administration of menstrual blood-derived stem cells and remdesivir for the treatment of severe coronavirus disease 2019 (COVID-19) induced pneumonia: A research protocol. URNCST Journal. 2022 Mar 02:

6(3). https://urncst.com/index.php/urncst/article/view/319

DOI Link: https://doi.org/10.26685/urncst.319

\section{Copyright}

(C) Andrew J. W. Cao, Daniel Jeyaraj, Henry Liu. (2022). Published first in the Undergraduate Research in Natural and Clinical Science and Technology (URNCST) Journal. This is an open access article distributed under the terms of the Creative Commons Attribution License (https://creativecommons.org/licenses/by/4.0/), which permits unrestricted use, distribution, and reproduction in any medium, provided the original work, first published in the Undergraduate Research in Natural and Clinical Science and Technology (URNCST) Journal, is properly cited. The complete bibliographic information, a link to the original publication on http://www.urncst.com, as well as this copyright and license information must be included.

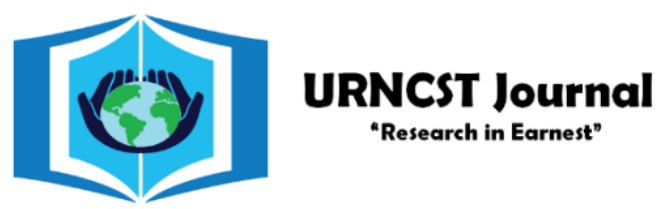

\section{Funded by the Government of Canada}

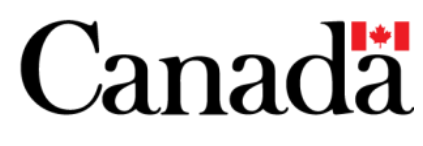

Do you research in earnest? Submit your next undergraduate research article to the URNCST Journal!

| Open Access | Peer-Reviewed | Rapid Turnaround Time | International | | Broad and Multidisciplinary | Indexed | Innovative | Social Media Promoted |

Pre-submission inquiries? Send us an email at info@ urncst.com | Facebook, Twitter and LinkedIn: @URNCST Submit YOUR manuscript today at https://www.urncst.com! 